\title{
FAKTOR-FAKTOR YANG MEMENGARUHI PERMINTAAN KREDIT CEPAT AMAN PADA PT. PEGADAIAN (PERSERO) CABANG MALILI
}

\author{
A. Dahri AP ${ }^{*}$, Salju ${ }^{1}$, Fitria Wijaksana Andi Lubis ${ }^{\mathbf{1}}$ \\ ${ }^{1}$ Sekolah Tinggi Ilmu Ekonomi Muhammadiyah Palopo \\ *Andidahri@stiem.ac.id
}

\begin{abstract}
Credit is one way to help the community in obtaining a loan. Based on the initial survey, the authors obtained the ones related to research on Customer Income, Interest Rates and Credit Requests (Survey at PT. Pegadaian Malili branch) and measured indicators of variables. in the study at. Based on the results of the regression proposed at Customer Income, there is a positive relationship to Credit Demand, while the Interest Rate has a negative relationship to Credit Demand at PT. Pegadaian Maili branch Hypothesis test results state that the Customer Income Variable and Interest Rate have a significant influence both simultaneously and partially on Credit Requests.

Keywords: Credit Request, Pawnshop
\end{abstract}

\begin{abstract}
Abstrak
Kredit merupakan salah satu cara untuk membantu masyarakat dalam mendapatkan pinjaman dana., berdasarkan survey awal penulis mendapatkan permasalahan yang terdapat di lokasi penelitian mengenai Pendapatan Nasabah, Suku Bunga dan Permintaan Kredit (Survey Pada PT. Pegadaian cabang Malili) dan mengukur indikator-indikator dari variabel pada penelitian in. Berdasarkan hasil uji regresi dinyatakan bahwa Pendapatan Nasabahmemiliki hubungan yang positif terhadap Permintaan Kredit, sedangkan Suku Bunga memiliki hubungan yang negatife terhadap Permintaan Kredit di PT. Pegadaian cabang Maili Hasil uji hipotesis menyatakan bahwa Variable Pendapatan Nasabah dan Suku Bunga memiliki pengaruh yang signifikan baik simultan maupun parsial terhadap Permintaan Kredit.
\end{abstract}

Kata Kunci: Permintaan Kredit, Pegadaian,

\section{PENDAHULUAN}

Kredit merupakan salah satu cara untuk membantu masyarakat dalam mendapatkan pinjaman dana. Berkaitan dengan kebutuhan dana bagi masyarakat untuk kegiatan konsumsi ataupun modal usaha, muncullah permintaan kredit. Kredit modal dapat digunakan masyarakat dalam membuka usaha, sedangkan kredit konsumsi digunakan masyarakat untuk mengkonsumsi barang tertentu.Selama ini PT Pegadaian lebih dekat dengan masyarakat dibandingkan dengan bank yang fungsinya sama-sama dapat membantu dan melepaskan beban keuangan.

Dalam menentukan jumlah penyaluran kredit gadai, PT Pegadaian akan dipengaruhi oleh kondisi internal dan kondisi eksternal. Faktor internal yang dimaksud yaitu bagaimana perusahan dapat mengelola dengan baik seperti manajemen asset perusahan dan faktor $5 \mathrm{c}$ (character, capacity, capital, collateral dan condition of economy) dalam manajemen kredit.
Termasuk di dalam faktor internal yaitu tingkat sewa modal atau nama lain tingkat suku bunga kredit gadai. Kredit Cepat Aman (KCA) adalah salah satu kegiatan uatama PT.Pegadaian. KCA ini merupakan pinjaman dana yang disalurkan masyarakat,dengan harapan masyarakat menggunakannya untuk berbagai kepentingan ekonomi yang dapat meningkatkan pertumbuhan ekonomi.

Berdasarkan uraian latar belakang masalah di atas maka penulis bermaksud untuk melakukan penelitian dengan judul " FAKTORFAKTOR YANG MEMENGARUHI PERMINTAAN KREDIT CEPAT AMAN PADA PT. PEGADAIAN (PERSERO) CABANG MALILI"

\section{KAJIAN PUSTAKA DAN PERUMUSAN HIPOTESIS}

\section{Pengertian Pegadaian}

PT Pegadaian (persero) adalah perusahaan milik pemerintah yang bertugas menyalurkan 
pinjaman atau kredit dengan jaminan benda bergerak. Kata kredit bukan hal yang asing dalam masyarakat, tetapi merupakan istilah yang sangat populer, baik dikalangan masyarakat perkotaan maupun perdesaan (Manurung, 2004)

\section{Pengertian Kredit}

Menurut Undang-undang No. 10 Tahun 1998, kredit adalah penyediaan uang atau tagihan yang dapat dipersamakan dengan itu, berdasarkan persetujuan atau kesepakatan pinjam meminjam antara bank dengan pihak lain yang mewajibkan pihak peminjam untuk melunasi utangnya setelah jangka waktu tertentu dengan pemberian bunga. Menurut Kasmir (2015), kredit diartikan memperoleh barang dengan membayar dengan cicilan atau angsuran di kemudian hari atau memperoleh pinjaman uang yang pembayarannya dilakukan di kemudian hari dengan cicilan atau angsuran sesuai dengan perjanjian

\section{Pendapatan Nasabah}

Menurut M.Munandar (1996) pendapatan suatu pertambahan assets yang mengakibatkan bertambahnya owners equity, tetapi bukan karena pertambahan modal baru dari pemiliknya dan bukan pula merupakan pertambahan assets yang disebabkan karena bertambahnya liabilities. Defenisi ini menjelaskan bahwa suatu pertambahan assets dapat disebut revenue apabila pertambahan assets tersebut berasal dari kontra prestasi yang diterima perusahaan atas jasa-jasa yang diberikan kepada pihak lain. Selanjutnya, pertambahan atau peningkatan assets akan mengakibatkan bertambahnya owner equity

\section{Suku Bunga}

Suku bunga adalah harga dari penggunaan atau biasa juga dipandang sebagai sewa atas penggunaan uang untuk jangka waktu tertentu, atau harga dari meminjam uang untuk menggunakan daya belinya dan biasanya dinyatakan dalam persen (\%). Teori Klasik menurut teori ini tinggi rendahnya tingkat suku bunga di tentukan oleh permintaan dan penawaran akan modal. Teori keynes keinginan memegang atau menahan uang didasarkan tiga alasan yaitu motif transaksi, berjaga-jaga,dan motif spekulasi

\section{METODE}

\section{Lokasi dan Waktu Penelitian}

Lokasi penelitian adalah di PT. Pegadaian (persero) Cabang Malili yang berlokasi di Jalan Andi Nyiwi Kelurahan Malili Kecamatan Malili Kabupaten Luwu Timur. Alasan utama pemilihan lokasi tersebut karena tempat tersebut merupakan Kantor Cabang Pegadaian di Kabupaten Luwu Timur

\section{Populasi dan Sampel}

Populasi yang digunakan dalam peneliti ini adalah seluruh nasabah PT. Pegadaian (persero) Cabang Malili yang mengajukan kredit di bulan februari 2016, menurut sumber dari PT. Pegadaian (persero) Cabang Malili yaitu sebanyak 134 nasabah. Sampel adalah bagian kecil dari anggota populasi yang diambil menurut prosedur tertentu sehingga dapat mewakili populasinya. Teknik pengambilan sampel dalam penelitian ini menggunakan teknik simple random sampling yaitu pengambilan secara acak yaitu sebanyak 100 nasabah PT. Pegadaian (persero) Cabang Malili

\section{Uji T-Statistik}

Uji t merupakan suatu pengujian yang bertujuan untuk mengetahui apakah masing-masing koefisien regresi signifikan atau tidak terhadap dependen variabel. Dengan menganggap variabel independen lainnya konstan. Dalam uji ini digunakan hipotesis sebagai berikut:

$H_{0}: b_{1}=0$, masing-masing variabel bebas tidak mempengaruhi variabel tidak bebas.

$\mathrm{H}_{0} \quad: \mathrm{b}_{1} \neq 0$, masing-masing variabel bebas mempengaruhi variabel tidak bebas

\section{Uji F-statistik}

Uji ini dilakukan dengan membandingkan nilai Fhitung dengan Ftabel. Jika $\mathrm{F}_{\text {hitung }}>\mathrm{F}_{\text {tabel, }}$ maka $\mathrm{H}_{0}$ ditolak, artinya variabel independen bersamaan mempengaruhi variabel dependen 


\section{Metode Analisis Data \\ Regresi Berganda}

Regresi berganda mencari hubungan antara satu variabel dependen dan dua atau lebih variabel independent. Dua atau lebih variabel independent akan mempengaruhi variabel dependen. Oleh karena itu regresi berganda merupakan metode yang akan meneliti ada atau tidaknya hubungan antara satu kejadian dengan sejumlah kejadian yang lain. Persamaan regresi linier yang terdiri dari dua variabel bebas dapat dinyatakan sebagai berikut (1) :

$$
\mathrm{Y}=\mathrm{a}+\mathrm{b} 1 \mathrm{X} 1+\mathrm{b} 2 \mathrm{X} 2+\varepsilon
$$

Dimana:

$$
\begin{array}{ll}
\mathrm{Y} & =\text { Permintaan Kredit di PT Pegadaian } \\
\mathrm{a} & =\text { Konstanta } \\
\mathrm{X} 1 & =\text { Pendapatan nasabah } \\
\mathrm{X} 2 & =\text { Suku Bunga } \\
\varepsilon & =\text { Kesalahan penduga }
\end{array}
$$

\section{HASIL DAN PEMBAHASAN}

Analisis regresi bertujuan untuk mengetahui derajat atau kekuatan hubungan dari variable. Maka dari itu akan dihitung nilai regresi dari variabel dalam penelitian ini yang mana hasilnya adalah sebagai berikut

$$
Y=4,177+0,440 \times 1-0,490 \times 2+0,963
$$

4,177 artinya : Jika variabel Permintaan Kredit tidak dipengaruhi oleh kedua variabel bebasnya yaitu Pendapatan Nasabah dan Suku Bunga, maka besarnya rata-rata Permintaan Kredit diramalkan akan Bernilai 4,177

0,440 artinya : Untuk setiap pertambahan nilai Pendapatan Nasabah sebesar 1\% maka diramalkan akan menyebabkan meningkatnya nilai satuan Permintaan Kredit sebesar 0.440 atau 44\%. Hal tersebut berarti Pendapatan Nasabah memiliki hubungan yang positif terhadap Permintaan Kredit.

$-0,490$, artinya : Untuk setiap penurunan nilai Suku Bunga sebesar 1\%, maka diramalkan akan menyebabkan meningkatnya nilai satuan Permintaan Kredit sebesar 0,490 atau 49\%. Hal tersebut berarti bahwa Suku Bunga memiliki hubungan yang negative terhadap Permintaan Kredit.
0,963 , berarti adalah nilai epselon atau tingkat pengaruh variabel lain, yang mempengaruhi Permintaan Kredit yang tidak dijadikan variable dalam penelitian

\section{Koefisien Determinasi}

Hasil uji koefisien determinasi diatas dapat diliha bahwa nilai koefisien determinasi hitung $\left(\mathrm{R}^{2}\right)$ berada di nilai 0,714. Maka dapat disumsikan bahwa terdapat peranan yang kuat dari variable bebas, yaitu Pendapatan Nasabah (X1) dan Suku BUnga (X2) terhadap Permintaan Kredit $(\mathrm{Y})$, karena nlai $\mathrm{R}^{2}$ semakin dekat dengan nilai maksimum, yaitu 1

\section{Uji T - Statistik}

\section{Uji T - Statistik Pendpatan Nasabah Terhadap Permintaan Kredit}

Dengan menggunakan SPSS 20, diperoleh hasil uji hipotesis X1 terhadap Y sebagai berikut:

Dapat diketahui nilai thitung untuk variabel Pendapatan Nasabah sebesar 6.149. Nilai ini akan dibandingkan dengan nilai ttabel pada tabel distribusi t. Dengan $\alpha=0,05$, untuk $n=100$, diperoleh nilai ttabel sebesar $\pm 1,66023$. Diketahui bahwa thitung untuk X2 sebesar 6.149 $>$ nilai ttabel 1,66023,dengan tingkat probabilitas $0.267>0,05$, maka H0 ditolak artinya variabel Pendapatan Nasabah secara

\begin{tabular}{|c|c|c|c|}
\hline \multicolumn{4}{|c|}{ Coefficients $^{a}$} \\
\hline Model & & $t$ & Sig. \\
\hline 1 & (Constant) & 4.339 & .350 \\
\hline & Suku_Bunga & -6.851 & .435 \\
\hline
\end{tabular}
parsial berpengaruh signifikan terhadap Permintaan Kredit

Uji T - Statistik Suku Bunga Terhadap Permintaan Kredit

Dengan menggunakan SPSS 20, diperoleh hasil uji hipotesis X2 terhadap Y sebagai berikut:

a. Dependent Variable: Permintaan_Kredit

Berdasarkan tabel di atas, dapat diketahui nilai thitung untuk variabel Suku Bunga sebesar 6.851. Nilai ini akan dibandingkan dengan nilai ttabel pada tabel distribusi t. Dengan $\alpha=0,05$, untuk $n=100$, 
diperoleh nilai ttabel sebesar $\pm 1,66023$. Diketahui bahwa thitung untuk X2 sebesar $6.851>$ nilai ttabel $-1,66023$ dengan tingkat probabilitas $0,435>0,05$, maka H0 ditolak artinya variabel Suku Bunga secara parsial berpengaruh signifikan terhadap Permintaan Kredit .

\section{Uji F - Statistik}

Pengujian ini dilakukan menggunakan distribusi $\mathrm{F}$ dengan membandingkan anatara nilai $\mathrm{F}$ - kritis dengan nilai F-test yang terdapat pada Tabel Analisis of Variance (ANOVA) dari hasil perhitungan dengan micro-soft. Jika nilai $\mathrm{F}_{\text {hitung }}>\mathrm{F}_{\text {kritis, }}$ maka $\mathrm{H}_{0}$ yang menyatakan bahwa variasi perubahan nilai variabel bebastidak dapat menjelaskan perubahan nilai variabel terikat ditolak dan sebaliknya. Berikut adalah hasil uji $F$ dari penelitian ini

\section{ANOVA $^{\text {a }}$}

\begin{tabular}{|ll|c|c|}
\hline Model & $F$ & Sig. \\
\hline 1 & Regression & 121.287 & $.185^{\mathrm{b}}$ \\
\hline
\end{tabular}

a. Dependent Variable: Permintaan_Kredit

b. Predictors: (Constant), Suku_Bunga, Pendapatan_Nasabah

Dari tabel diatas, diperoleh nilai F hitung sebesar 121,287. Karena nilai F hitung 121,287> F tabel untuk $\mathrm{n}=100=3,090$ dengan probabilitas 0,185 $>0,05$, maka dapat ditarik kesimpulan bahwa Ho ditolak. Dengan demikian dapat dikatakan jika terdapat pengaruh dari Penghasilan Nasabah dan SUku Bunga terhadap Permintaan Kredit secara simultan

\section{SIMPULAN}

Berdasarkan hasil penelitian dan penjelasan, serta pembahasan yang disertai dengan teori dan konsep yang mendukung mengenai penelitian ini maka didapatkan kesimpulan bahwa penelitian ini menunjukkan adanya pengaruh secara parsial dari Pendapatan Nasabah (X1) terhadap Permintaan Kredit (Y) pada PT. Pegadaian (Persero) cabang Malili, hal ini ditunjukkan dengan nilai $\mathrm{T}$ hitung sebesar 6,149 dengan tingkat probabilitas 0,267 >0,05.
Hasil T hiutng sebesar $-6,851$ dengan tingkat probabilitas 0,435 $>0,05$ membuktikan bahwa terdapat pegaruh negative dari Suku Bunga (X2) terhadap Permintaan Kredit (Y) pada PT Pegadaian (Persero) cabang Malili. Pendapatan Nasabah (X1) dan Suku Bunga (X2) secara bersama - sama memiliki pengaruh terhadap Permintaan Kredit (Y) pada PT. Pegadaian (Persero) cabang Malili, hal ini ditunjukkan dengan nilai $\mathrm{F}$ hitung sebesar 121,87 dengan tingkat probabilitas 0,185 >0,05

\section{DAFTAR PUSTAKA}

[1] Agung, I.G.N.,N.H.A. Pasay, Sugiharto. 2008. Teori Ekonomi Mikro, Suatu Analisis Produksi Terapan. Jakarta: PT. Raja Grafindo.

[2] Anoraga, P. \& J. sudantoko.2002. Koperasi, kewirausahaan dan usaha kecil. Jakarta : Rineka Cipta.

[3] Asri. 2010. Analisis Usaha Industri Emping Melinjo Skala Rumah Tangga Di Kabupaten Magetan. Surakarta : Skripsi. FakultasPertanian, Universitas Sebelas Maret

[4] Basrowi Dan Suwandi. 2008. Memahami Penelitian Kualitatif. Jakarta: Rineka Cipta.

[5] Buchari, A. 2007.Manajemen Pemasaran Dan Pemasaran Jasa. Bandung : Alfabeta.

[6] Martin, P. 2000. Mengembangkan Usaha Kecil. Jakarta : Murai Kencana PT Raja Grafindo Persada.

[7] Pawe, S. 2007. Peranan Industri Rumah Tangga Dalam PeningkataN Pendapatan Masyarakat Di Desa Roworeno Kecamatan Ende Selatan Kabupaten Ende. Malang :Skripsi. Universitas Islam Negeri.

[8] Profil Desa Sorowako tahun 2016.

[9] Rahmawati, F. 2015. Industri Kerupuk Sebagai Sarana Peningkatan Perekonomian Masyarakat. Yogyakarta :Skripsi. Fakultas Dakwah dan Komunikasi. Universitas Islam Negeri Sunan Kalijaga

[10] Sigit W dan S. Ismaya, 2007 kamus besar ekonomi : 252

[11] Sujatmiko, Eko. 2014. Kamus IPS. Surakarta: Aksara Sinergi Media Cetakan I halaman 117. 
[12] Sumodiningrat, G. 1998. Membangun Perekonomian Rakyat. Yogyakarta: Pustaka Pelajar.

[13] Sutrisno. 2000. Manajemen Keuangan (Teori, Konsep dan Aplikasi). Yogyakarta :Ekonosia.

[14] Basu, S. 2000, Pengantar Bisnis Modern, Pengantar Ekonomi Perusahaan Modern, Jakarta : Liberty

[15] Alfian Budikusuma,2014, Analisa Penetapan Harga Jual Unit arumah Pada Pengembangan Perumahan Grand Mandiri Residence, Depok

[16] Heizer, J. dan R. Barry. 2004. Manajemen Operasi. Jakarta : Salemba Empat 